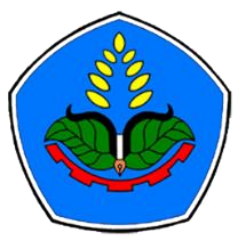

AGROPROSS

National Conference

Proceedings of Agriculture

\section{Proceedings: \\ Peran Teaching Factory Di Perguruan Tinggi Vokasi Dalam \\ Mendukung Ketahanan Pangan Pada Era New Normal}

Tempat : Politeknik Negeri Jember

Tanggal : 8-9 Juli 2020

\section{Publisher:}

Agropross, National Conference Proceedings of Agriculture

ISBN : 978-623-94036-6-9

DOI : 10.25047/agropross.2020.6

\title{
Pemanfaatan Limbah Kardus dan Bekatul Sebagai Media Budidaya Jamur Tiram Putih (Pleurotus ostreatus)
}

\author{
Author(s): Nurhaida Widiani ${ }^{(1) *}$; Amalia Fatimah ${ }^{(1)}$; Rina Budi Satiyarti ${ }^{(1)}$ \\ (1) Program Studi Pendidikan Biologi, Fakultas Tarbiyah dan Keguruan, UIN Raden Intan \\ * Corresponding author: nurhaidawidiani@radenintan.ac.id
}

\begin{abstract}
Cardboard waste is household waste containing cellulose and hemicellulose which may be used as growth media for Pleurotus ostreatus. It is a fungus that is consumed by many people. One effort to increase mushroom production is by improving the quality of the cultivation media. The purpose of this study was to determine the effect of cardboard waste on the growth of it. This research is an experimental study using a Completely Randomized Design (CRD) consisting of 5 treatments and 4 replications. The treatments in this study were $K 0=0 \%$ (without being given cardboard waste), $K 1=50 \%$ cardboard waste $+30 \%$ bekatul, $\mathrm{K} 2=60 \%$ cardboard waste $+25 \%$ bekatul, $\mathrm{K} 3=70 \%$ cardboard waste $+20 \%$ bekatul, and K4 $=80 \%$ cardboard waste +15 bekatul. The parameters observed were the day of mycelium fulfillment, the number of fruit bodies, hood width, wet weight and stem length. The data obtained were analyzed using the One Way Anova test and if there was an effect continued by the Least Significant Difference test (LSD). The results showed that cardboard waste treatment affected the growth of fungi, namely on the parameters of mycelium fulfillment days, the number of fruit bodies, hood width, and wet weight. The best treatment as a medium to grow white oyster mushroom (Pleurotus ostreatus) is the K3 treatment.
\end{abstract}

\section{Keyword:}

Cardboard waste;

Cellulase;

Cultivation:

hemicellulase;

Pleurotus

ostreatus;

\section{Kata Kunci:}

Budidaya;

Hemiselulosa;

Limbah kardus;

Pleurotus

ostreatus;

Selulosa;

\begin{abstract}
ABSTRAK
Limbah kardus merupakan limbah rumah tangga yang mengandung selulosa dan hemiselulosa yang mungkin dapat dimanfaatkan sebagai media pertumbuhan jamur tiram putih (Pleurotus ostreatus). Jamur tiram putih (Pleurotus ostreatus) merupakan jamur yang banyak dikonsumsi masyarakat. Salah satu upaya untuk meningkatkan produksi jamur adalah dengan memperbaiki kualitas media budidaya. Tujuan penelitian ini adalah mengetahui pengaruh limbah kardus dan bekatul terhadap pertumbuhan jamur tiram putih (Pleurotus ostreatus). Penelitian ini merupakan penelitian eksperimen menggunakan Rancangan Acak Lengkap (RAL) yang terdiri dari 5 perlakuan dan 4 kali ulangan. Perlakuan dalam penelitian ini adalah $\mathrm{K} 0=0 \%$ (tanpa diberi limbah kardus dan bekatul), $\mathrm{K} 1=50 \%$ limbah kardus $+30 \%$ bekatul, $\mathrm{K} 2=60 \%$ limbah kardus $+25 \%$ bekatul, $\mathrm{K} 3=$ $70 \%$ limbah kardus $+20 \%$ bekatul dan $\mathrm{K} 4=80 \%$ limbah kardus $+15 \%$ bekatul. Parameter yang diamati yaitu hari pemenuhan miselium, jumlah badan buah, lebar tudung, berat basah dan panjang tangkai. Data yang diperoleh dianalisis menggunakan uji One Way Anova dan apabila terdapat pengaruh dilanjutkan uji Beda Nyata Terkecil (BNT). Hasil penelitian menunjukkan adanaya pengaruh perlakuan limbah kardus terhadap pertumbuhan jamur yaitu pada parameter hari pemenuhan miselium, jumlah badan buah, lebar tudung, dan berat basah. Perlakuan yang paling baik sebagai media tumbuh jamur tiram putih (Pleurotus ostreatus) yaitu perlakuan K3.
\end{abstract}




\section{PENDAHULUAN}

\begin{tabular}{llrr}
\multicolumn{2}{c}{ Sektor pertanian } & \multicolumn{2}{r}{ mempunyai } \\
peranan vital & dalam & \multicolumn{2}{c}{ menyokong } \\
perekonomian & Indonesia. & Untuk \\
mengembangkan & sektor & tersebut \\
diperlukan sinergi & yang baik & antara \\
pemerintah dan & pihak & swasta. \\
Peningkatan nilai tambah & produk \\
pertanian & diharapkan & dapat \\
meningkatkan & \multicolumn{3}{c}{ kesejahteraan } \\
masyarakat. & \multicolumn{3}{c}{$r$}
\end{tabular}

Salah satu produk pertanian yang memiliki nilai ekonomi dan banyak dikonsumsi masyarakat adalah jamur. Budidaya jamur tidak menggunakan pupuk dan pestisida kimiawi sehingga aman untuk dikonsumsi. Selain itu lahan yang diperlukan untuk budidaya jamur juga tidak terlalu luas. Jamur tiram (Pleurotus Ostreatus) mempunyai peluang usaha yang baik untuk dikembangkan karena harga jualnya yang cukup tinggi. Jamur ini mengandung karbohidrat 57,6-81,8 gram, protein 7,8-17,72 gram, lemak 12,3 gram, serat kasar 5,6-8,7 gram, Ca 21 $\mathrm{mg}$, Fe $32 \mathrm{mg}$, thiamin 0,21 $\mathrm{mg}$, riboflavin 7,09 gram (Widyastuti \& Istini, 2004). Jamur ini baik dikonsumsi masyarakat Indonesia yang masih sulit dalam pemenuhan kebutuhan gizi harian yang lengkap terutama kebutuhan akan protein.

Untuk budidayanya, jamur tiram membutuhkan media yang mengandung nutrisi yang diperlukan yaitu lignin, karbohidrat (selulosa dan glukosa), protein, nitrogen, serat, dan vitamin. Media tanam yang banyak mengandung selulosa yang biasanya digunakan untuk budidaya jamur ini adalah serbuk gergaji, jerami, sekam, ampas tebu, ampas aren, kelapa, serta limbah kertas (Afief et al., 2015). Kardus merupakan salah satu limbah kertas yang mengandung selulosa, hemiselulosa, dan lignin yang diperlukan untuk pertumbuhan jamur. Kardus merupakan limbah rumah tangga yang biasanya digunakan hanya untuk pengemasan namun belum banyak dimanfaatkan oleh masyarakat dalam bidang pertanian. Berdasarkan penelitian yang dilakukan oleh Pamungkas (2018), budidaya jamur tiram dengan menggunakan limbah kardus dan pupuk cair organik tidak memberikan pengaruh bagi pertumbuhan jamur tiram. Akan tetapi penelitian yang dilakukan oleh Haryani dkk (2016) menunjukan hasil bahwa media limbah kardus yang ditambah ampas tahu mempengaruhi pertumbuhan jamur tiram putih.

Selain penggunaan limbah kardus, media pertumbuhan jamur tiram juga dapat ditambahkan bekatul. Bekatul merupakan hasil samping penggilingan padi yang masih banyak mengandung karbohidrat, protein, lemak, vitamin, dan mineral. Penambahan bekatul pada media serbuk kayu karet memberikan pengaruh pada awal muncul miseliu, berat basah tubuh buah, dan jumlah tubuh buah jamur tiram, tetapi tidak berpengaruh pada diameter tudung jamur tiram (Setiadi., et al., 2015). Untuk itu pada penelitian ini bertujuan melihat pengaruh limbah kardus dan bekatul pada budidaya jamur tiram.

\section{METODE PENELITIAN Tempat dan Waktu}

Penelitian ini dilaksanakan pada bulan Mei - Juni 2018 di desa Bumi Mulya, Kabupaten Way Kanan.

\section{Alat dan Bahan \\ Alat yang digunakan dalam penelitian ini antara lain dandang, wajan, baskom, ember, kayu pengaduk, tungku, plastik baglog, ruang inokulasi, lilin, spatula, kertas koran, tisu, bak, timbangan, hygrometer, termometer, paralon, karet gelang, gunting, penggaris plastik, ruang sterilisasi, kamera, buku, pulpen, label, dan isolatip. Bahan yang}


digunakan dalam penelitian ini antara lain: kardus, bibit F2, alkohol, bekatul, kapur $(\mathrm{CaCo} 3)$, dan jagung.

\section{Cara Kerja}

Penelitian ini merupakan penelitian eksperimen menggunakan Rancangan Acak Lengkap dengan 5 perlakuan dan 4 ulangan. Perlakuannya adalah

$\mathrm{K} 0=$ Serbuk kayu $60 \%$ : bekatul $20 \%$

$\mathrm{K} 1=$ Limbah kardus 50\% : bekatul 30\%

$\mathrm{K} 2=$ Limbah kardus $60 \%$ : bekatul $25 \%$

$\mathrm{K} 3=$ Limbah kardus $70 \%$ : bekatul 20\%

$\mathrm{K} 4=$ Limbah kardus 80\%: bekatul 15\%

Kardus dibersihkan dari bendabenda yang menempel kemudian disobek kecil-kecil ukuran 3 x $3 \mathrm{~cm}$ dan direndam dengan air kapur pertanian selama 24 jam. Kardus direbus selama 2 - 3 jam hingga suhu $28-30^{\circ} \mathrm{C}$, lalu ditiriskan hingga kadar air berkurang 95\%. Kardus dicampur dengan bekatul, kapur pertanian, dan pupuk organik. Media yang sudah tercampur rata dimasukkan kedalam kantong plastik PE ukuran $15 \times 25 \mathrm{~cm}$, dipadatkan dan diikat dengan karet. Media tersebut kemudian disterilisasi menggunakan dandang selama $7-8$ jam. Setelah media siap, bibit jamur diinokulasi kemudian inkubasi selama 30 - 50 hari pada suhu ruangan.

Parameter yang diamati adalah hari pemenuhan miselium, jumlah badan buah, lebar tudung, berat basah, dan panjang tangkai. Selanjutnya data penelitian dianalisis dengan uji One Way ANOVA. Apabila terdapat pengaruh maka dilanjutkan uji BNT/LSD.

\section{HASIL DAN PEMBAHASAN}

Hasil penelitian menunjukan bahwa limbah kardus dan bekatul cukup baik untuk dijadikan media budidaya jamur tiram putih. Berdasarkan penelitian yang telah dilakukan maka didapatkan hasil yang dapat dilihat pada tabel 1. Perlakuan K3 menunjukan hasil terbaik jika dibandingkan perlakuan lainnya yaitu pada parameter jumlah badan buah, berat basah, dan panjang tangkai. Meskipun untuk parameter hari pemenuhan miselium perlakuan yang menunjukan hasil yang lebih baik adalah $\mathrm{K} 1$, begitu juga untuk parameter lebar tudung perlakuan yang menunjukan hasil yang lebih baik adalah K4.

Tabel 1. Analisis Pertumbuhan Jamur Tiram Putih

\begin{tabular}{|l|l|l|l|l|l|}
\hline Perlakuan & $\begin{array}{l}\text { Hari } \\
\text { Pemenuhan } \\
\text { Miselium }\end{array}$ & $\begin{array}{l}\text { Jumlah } \\
\text { Badan Buah }\end{array}$ & $\begin{array}{l}\text { Lebar } \\
\text { Tudung } \\
(\mathrm{cm})\end{array}$ & $\begin{array}{l}\text { Berat Basah } \\
\text { (gram) }\end{array}$ & $\begin{array}{l}\text { Panjang } \\
\text { Tangkai } \\
(\mathrm{cm})\end{array}$ \\
\hline K0 & $13,75 \mathrm{a}$ & $4,00 \mathrm{a}$ & $9,00 \mathrm{~b}$ & $63,75 \mathrm{a}$ & 3,25 \\
\hline K1 & $17,50 \mathrm{~b}$ & $13,50 \mathrm{~d}$ & $7,00 \mathrm{a}$ & $61,75 \mathrm{~b}$ & 3,00 \\
\hline K2 & $14,50 \mathrm{a}$ & $8,75 \mathrm{~b}$ & $9,25 \mathrm{~b}$ & $66,25 \mathrm{a}$ & 3,75 \\
\hline K3 & $14,75 \mathrm{a}$ & $13,50 \mathrm{~d}$ & $9,25 \mathrm{~b}$ & $72,75 \mathrm{c}$ & 4,00 \\
\hline K4 & $14,25 \mathrm{a}$ & $6,25 \mathrm{c}$ & $10,25 \mathrm{~b}$ & $55,00 \mathrm{~b}$ & 3,00 \\
\hline
\end{tabular}


Hasil uji anova menunjukan adanya pengaruh yang nyata dari penggunaan limbah kardus dan bekatul untuk hari pemenuhan miselium, jumlah badan buah, lebar tudung, dan berat basah. Sedangkan untuk parameter panjang tangkai tidak menunjukan adanaya pengaruh penggunaan media limbah kardus dan bekatul.

Kandungan nutrisi media tanam, intensitas cahaya, dan kelembaban mempengaruhi pertumbuhan jamur. Kardus mengandung selulosa dan lignin yang diperlukan untuk pertumbuhan jamur tiram putih. Selulosa merupakan komponen utama penyusun kayu yang secara enzimatis akan terurai dan dimanfaatkan untuk pertumbuhan jamur (Suparti \& Marfuah, 2015). Lignin dapat mempercepat tumbuhnya jamur. Lignin yang terdegradasai dapat dimanfaatkan untuk pembentukan hifa dan miselium. Berdasarkan penelitian diduga penggunaan kardus $50 \%$ (K1) merupakan komposisi media terbaik untuk hari pembentukan miselium. Menurut Sukmadi (2012) pertumbuhan miselium yang baik akan mempengaruhi kecepatan pembentukan badan buah. Hal ini bisa dilihat dari hasil untuk jumlah badan buah pada K1 juga cukup baik.

Penggunaan kardus diduga juga menyebabkan penambahan kelembaban media, sehingga berat jamur tiram akan lebih baik. Berdasarkan penelitian berat basah yang paling baik adalah perlakuan K3.

Selain dari limbah kardus, bekatul juga menyediakan nutrisi yang diperlukan untuk pembentukan miselium. Bekatul mengandung thiamin (vitamin B1) yang berperan sebagai kofaktor enzim lignolitik yang dapat mengoptimalkan degradasi selulosa yang terkandung pada kardus . Bekatul mengandung protein yang dapat mempercepat pembentukan miselium (Muchsin et al., 2017). Bekatul juga mempengaruhi banyaknya tubuh buah yang terbentuk.

\section{KESIMPULAN}

Berdasarkan penelitian yang telah dilakukan dapat disimpulkan bahwa limbah kardus dan bekatul berpengaruh terhadap pertumbuhan jamur yaitu pada parameter hari pemenuhan miselium, jumlah badan buah, lebar tudung, dan berat basah. Tetapi tidak berpengaruh terhadap panjang tangkai. Perlakuan yang paling baik sebagai media tumbuh jamur tiram putih (Pleurotus ostreatus) yaitu perlakuan K3.

\section{DAFTAR PUSTAKA}

Afief, M.A., R.R. Lahay, B. Siagian. 2015. Respon Pertumbuhan dan Produksi Jamur Tiram Putih (Pleurotus ostreatus) Terhadap Berbagai Media Serbuk Kayu dan Pemberian Pupuk NPK. Jurnal

Agroteknologi.Vol,3.No,4

Haryani, T.S., A, Apriliyani, S.Y.S. Rahayu. 2016. .Pemanfaatan Limbah Ampas Teh dan Kardus Sebagai Media Pertumbuhan dan Produktivitas Jamur Tiram Putih. Prosiding semnas

Muchsin, A.Y., W.E. Murdiono, dan M.D. Maghfoer. 2017. Sukmadi, H., Hidayat, N., \& Lestari, E. R. (2012). Pengaruh Penambahan Sekam Padi dan Bekatul Terhadap Pertumbuhan dan Hasil Jamur Tiram Putih (Pleurotus ostreatus). Journal of Agricultural Science. Vol 2(1): 30 38.

Pamungkas, S.S.T. 2018. Pemanfaatan Limbah Kardus dan Pupuk Organik Cair sebagai Campuran Media Tanam Pertumbuhan Jamur Tiram Putih (Pleurotus ostreatus). Journal of Applied Agricultural Sciences. Vol. 2, No. 1, Hal. 61-66 
Setiadi, A.R., F.Y. Ade, R.R.Lubis. 2015. Pengaruh Takaran Dosis Bekatul Pada Medium Serbuk Kayu Karet Terhadap Hasil Produksi Jamur Tiram Putih (Pleurotus Ostreatus). Jurnal Ilmiah Mahasiswa FKIP

Sukmadi, H., Hidayat, N., \& Lestari, E. R. (2012). Optimasi Produksi Jamur Tiram Abu-abu (Pleurotus sojarcaju) Pada Campuran Serat Garut dan Jerami Padi. Jurnal Teknologi Pertanian, 4(1), 1-12.

Suparti dan L.Marfuah. 2015. Produktivitas Jamur Tiramputih (Pleurotus ostreatus) pada Media Limbah Sekam Padi dan Daun Pisang Kering Sebagai Media Alternatif

Widyastuti. N dan S. Istini. 2004. Optimasi Proses Pengeringan Tepung Jamur Tiram Putih (Pleurotus ostreatus). Jurnal Ilmu Kefarmasian Indonesia (2): $1-4$ 